\title{
THE IMPACT OF INTERACTIVITY, PERCEIVED EFFECTIVENESS, TRUST, AND EXPERIENTIAL MARKETING ON ONLINE TRANSPORTATION CUSTOMER LOYALTY
}

\author{
Ananda Sabil Hussein 1 , Raditha Hapsari ${ }^{*}$ \\ 'Management Department, Faculty of Economics and Business, Universitas Brawijaya \\ Address: ' JI. MT. Haryono No. 165, Malang, Jawa Timur, Indonesia 65145 \\ *E-mail: radhita.hapsari@ub.ac.id
}

\begin{abstract}
The purpose of this study is to examine the effect of interactivity, perceived effectiveness, trust, and experiential marketing on online transportation customers' loyalty in Indonesia. This study surveyed 264 online transportation customers. Purposive sampling was used to recruit respondents. Partial Least Squares analysis was used to analyze the data in three steps, including inner model analysis, outer model analysis, and hypothesis testing. The hypothesis testing supported seven of the nine hypotheses proposed. The findings of this study indicate that interaction is a significant predictor of online transportation consumer loyalty. The report also discusses the implications of the results and the direction for further research.
\end{abstract}

Keywords: Interactivity, perceived effectiveness, trust, experiential marketing, customer loyalty JEL Classification: M1, M2, M3

\section{Article History:}

Received: September 20, 2021; Revised: November 29, 2021; Accepted : December 2, 2021; Available Online : December 12, 2021

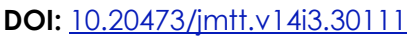

\section{INTRODUCTION}

Globalization has had a significant impact on the development of the corporate world worldwide. The market is wide open, and the prospects are expanding, but the competition is becoming more unpredictable. Digital technology is widely seen as playing a critical influence in a country's economy. This condition necessitates that each business has a competitive advantage to compete sustainably with other businesses in the same field. The rapid advancement of information technology has increased the community's desire to continue increasing the economy's and industry's productivity. Business in the sphere of public transportation services is a lucrative opportunity at the moment. When combating congestion, online transportation services such as Grab and Gojek are extremely appropriate and effective alternatives. Every one prefers to utilize these online transportation services since they can get to their location quickly and efficiently.

During today's fierce competition, transportation service providers compete to offer consumers their services with their unique benefits. As a result, the corporation has taken numerous measures to ensure consumer loyalty-increasing customer loyalty through improved service and a commitment to providing the best for customers. According to a prior study, a sense of customer loyalty to a brand is critical for a business's survival. According to 
(Giddens, 2002), brand-loyal consumers exhibit qualities such as commitment to the brand, willingness to pay a premium for the brand, recommending the brand to others, making repeat purchases, and being constantly informed about the brand. When consumers conduct business with a company, they expect a memorable encounter, colloquially referred to as a customer experience. Thus, one may argue that a consumer experience is a form of capital that businesses can leverage to build consumer loyalty. Additionally, it is vital to ensure that consumers perceive the success of a corporate organization's transactions and consumption of its services when building consumer trust. Consumer confidence is also projected to rise due to increased communication and interactive connections between service providers and consumers.

Although research on loyalty and the antecedents of loyalty has been widely explored, research on the loyalty of online transportation users is still rarely done. Furthermore, the characteristics of online transportation are quite different from those of other industries that have been studied. For example, Chang (2020) examines experiential marketing and loyalty to coffee shops; Molinillo et al. (2017) in the online shopping clothes industry. Furthermore, Zheng, Lee and Cheung (2017) makes research on the antecedents of online transportation loyalty important to do. Furthermore, the interaction of the emerging marketing constructs such as interactivity and perceived effectiveness will increase the predictive power of the model, as well as close the gap in the literature on antecedent online transportation loyalty. Thus, this research investigates the interrelationship between interactivity, perceived effectiveness, trust, experiential marketing, and online transportation loyalty. Furthermore, this current research will also provide a practical benefit for online transportation practitioners. The practitioners can allocate their resources efficiently to enhance the loyalty of online transportation users.

\section{LITERATURE REVIEW AND HYPOTHESES}

\section{Consumer Loyalty}

Loyalty is a significant issue in marketing research (Nguyen, Barrett and Miller, 2011). Loyalty is described as a commitment made by consumers to purchase their chosen product/service in the future, resulting in recurring purchases with the same brand regardless of situational or marketing pressures that may trigger switching behavior (Lee, 2021). Consumer loyalty is a competitive advantage since it implies the ability of businesses to produce future revenue over time (O'Connor and Kelly, 2017; Carayannis et al., 2017). Consumer loyalty can be measured by consumers' recurrent purchases of brands and products (Krystallis and Chrysochou, 2014; Romaniuk and Thiel, M, 2013). Creating brand loyalty has gotten more difficult as competitors' offers have become more comparable and their corporate principles have become more similar (Dawes, Meyer-Waarden and Driesener, 2015). In this regard, it is critical to establish and 


\section{Ananda Sabil Hussein \\ Raditha Hapsari}

maintain strong relationships with consumers to earn their loyalty (Gbadamosi, 2015). According to Foroughi et al. (2019), loyalty is typically quantified in terms of two dimensions: attitudes and conduct. While attitude loyalty refers to customer feelings and psychological states (Ahn and Back, 2018; Kim et al., 2020), behavioral loyalty refers to repurchase or reuse behavior (Chung, Brown and Willett, 2019)

Trust is the antecedent of loyalty. The significant and positive effect of consumer trust on their loyalty has been proven repeatedly by Lin et al., (2011); Kang and Hur (2012); Frasquet, Descals and Ruiz-Molina (2017); Park, Kim and Kwon (2017). Research by Das (2016) and Khan, Rahman and Fatma (2016) show, respectively, that trust (online) can positively influence consumer behavioral intentions (purchase intentions, repurchases, and recommendations) and consumer loyalty.

\section{Interactivity}

Interactivity is a two-way connection between users and computer technology that occurs regardless of space or time. Users can alter the form and content of the communication in real-time (Yoo, Yunjung and Jung, 2010). Interactivity, according to a prior study, can be categorized into three components: control, synchronization, and two-way communication (Purwanto and Kuswandi, 2017; Yoo, Yunjung and Jung, 2010). Controllability is defined as the amount to which the communicant can change the communication's content, timing, and sequencing (Park, Jun and Lee, 2015). Second, synchronization relates to the rate at which information is communicated and the response that enables communication. Thirdly, two-way communication enables the swap of roles between the sender and recipient of communications (Purwanto and Kuswandi, 2017).

Interactivity on websites is critical for promoting positive behavioral intentions among online clients (Jeon et al., 2016). Real-time online interaction has a noticeable positive influence on consumer loyalty (Etemad-Sajadi, 2016). Numerous prior researches have established a positive correlation between interaction and consumer loyalty (Boateng, 2019; Khan, Rahman and Fatma, 2016; Kandampully, Zhang and Bilgihan, 2015). Businesses must leverage online interaction tools by consistently upgrading the stability and functionality of their online platform in order to retain customers and increase loyalty (Boateng, 2019). Thus, businesses can leverage online platforms to foster customer involvement via responses, questions, comments, feedback, and criticism (Boateng, 2019). It will, in turn, affect customer experience, trust, and customer perception of service effectiveness. Thus, the following hypotheses are formulated:

\section{H1: Interactivity has a positive and significant effect on perceived effectiveness \\ H2: Interactivity has a positive and significant effect on trust \\ H3: Interactivity has a positive and significant effect on experiential marketing}




\section{Perceived Effectiveness}

Perceived effectiveness is a performance expectation that quantifies the amount to which consumers benefit from using technology when doing certain tasks (Lehto and OinasKukkonen, 2015; Venkatesh, Thong and Xu, 2012). Perception of effectiveness on online platforms as a proxy for how users view the efficacy of online platforms' processes compared to traditional enterprises (Adaji and Vassileva, 2017). Effectiveness is viewed favorably by online transportation customers, as are services that fit their demands and reasonable prices compared to the services received (Putri, Amin and Warjio, 2019).

Numerous prior studies have clarified the relationship between perceived effectiveness and customer loyalty (Lehto and Oinas-Kukkonen, 2015; Huang et al., 2015; Fang et al., 2014). Consumer behavior in the future will be influenced by the efficacy of online platforms in supplying products and services to consumers (Adaji and Vassileva, 2017). Users who believe an online platform effectively assists others will continue to utilize it, thereby increasing loyalty (Lehto and Oinas-Kukkonen, 2015). The following hypotheses are formulated:

\section{H5: Perceived effectiveness has a positive and significant effect on trust}

H6: Perceived effectiveness has a positive and significant effect on experiential marketing H7: Perceived effectiveness has a positive and significant effect on loyalty

\section{Trust}

According to consumer behavior and marketing literature, trust is critical in establishing longterm connections (Islam et al., 2021). Customer trust can influence consumer loyalty to service providers and customer views of the service's value. Consumer loyalty is a long-term investment that explains the relationship between customers and service providers in a straightforward manner (Raza et al., 2020). Consumer loyalty is defined as a dedication to establishing longterm relationships with businesses through repeated purchases of their products/services (Markovic et al., 2018). Loyalty behavior encompasses all aspects of behavior associated with loyalty, such as repurchase, repurchase, or return visits to a product/service/location. Earlier research has revealed several significant determinants of consumer loyalty, most notably consumer trust (Markovic et al., 2018; Leonidou, Kvasova and Leonidou, 2013). Customers' perceptions of a brand's trustworthiness tend to be favorable, which might raise their level of loyalty toward particular brands (Liu, Cheng and Ouyang, 2021). The following hypothesis is:

\section{H8: Trust has a positive and significant effect on loyalty}

\section{Experiential Marketing}

Marketing plays a critical role in developing an organization's competitive strategy (Storey, 2017). The service industry's competition has compelled businesses to incorporate changes in 


\section{Ananda Sabil Hussein Raditha Hapsari}

economic value that stem not only from services/goods but also from experiential marketing (Kalantari, H. and Johnson, 2018). Experience-based marketing is growing more popular in today's economic climate. Experiential marketing is the most cutting-edge strategy in marketing communications, utilizing sensory appeal and wide imagery to enhance the consumer experience (Levy and Guterman, H, 2020; Yeh, Chen and Chen, 2019; Wiedmann et al., 2018; Chaney, Lunardo and Mencarelli, 2018). This method is theoretically grounded in the "experiential view," which views consumption as a subjective phenomenon, a state of emotional awareness (Yeh, Chen and Chen, 2019; Ding and Tseng, 2015). The sensory appeal is a fundamental component of the consumer experience that shapes consumers' overall feelings about a brand. Consumers' expressed emotions and thoughts will be presumed to have an effect on brand-related emotions and thoughts manifested in affective and cognitive reactions (Meng-Shiou, Li-Fen and Li-Wen, 2019). The critical factor in increasing customer loyalty is customer-generated experience marketing for a product, brand, or service (Sonderlund, 2018). Schmitt (1999) identified four primary characteristics of experiential marketing: (1) an emphasis on experiential marketing; (2) a focus on consumption as a holistic experience; (3) an assumption that customers are rational and emotional beings; and (4) an appreciation for the eclectic nature of methods and tools. To expand on the concept of experience, Schmitt (1999) suggests five distinct forms of experience: "sense," "feel," "think," "act," and "relate." Previous research on various industries has noted that experiential marketing affects loyalty (Ding and Tseng, 2015; Wiedmann et al., 2018; Hussein and Hapsari, 2020). Thus, the following hypothesis is formulated:

\section{H9: Experiential marketing has a positive and significant effect on loyalty}

The conceptual model of this research is as follows

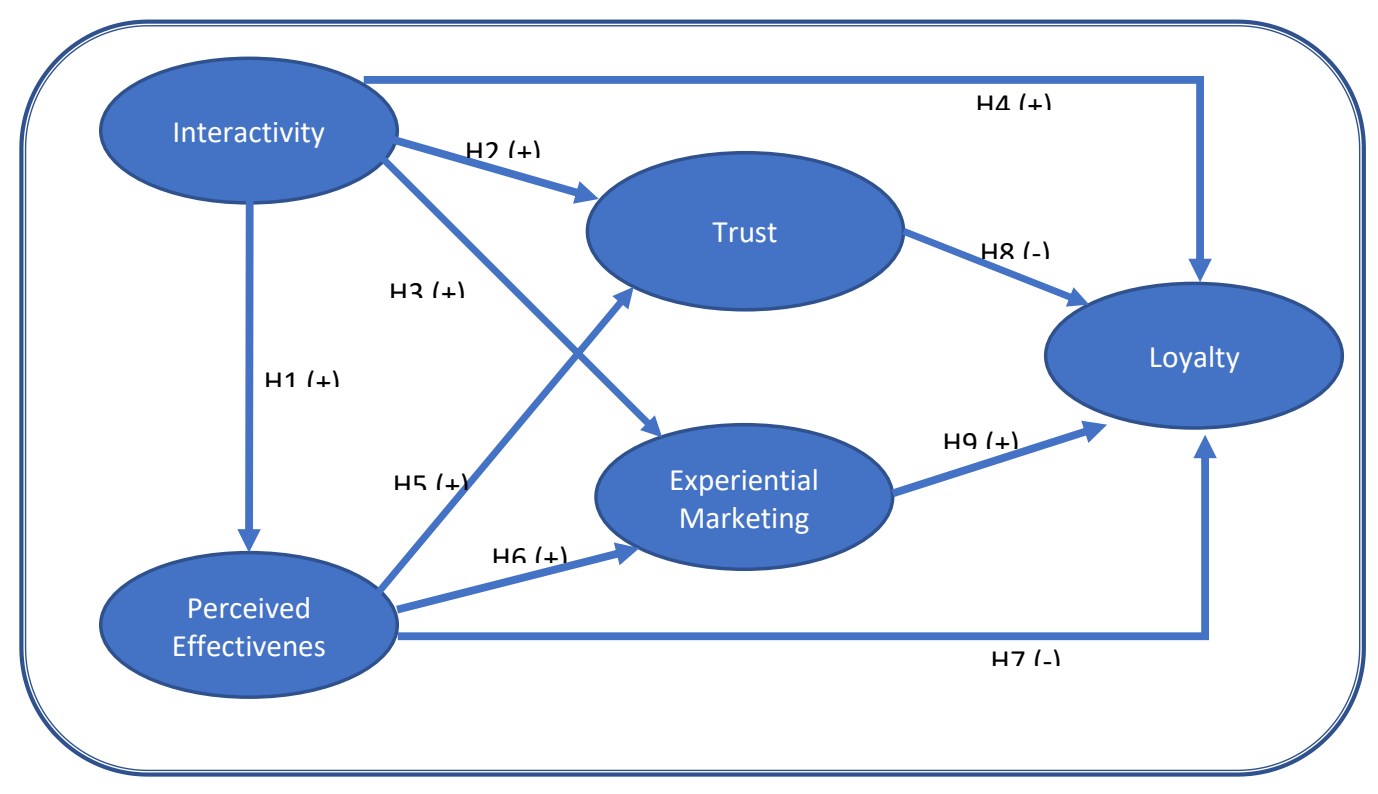

Figure 1.

Conceptual Research Model 


\section{RESEARCH METHODS}

This study is explanatory research that examines the relationship among interactivity, perceived effectiveness, trust, experiential marketing, and loyalty. The population of this study is online transportation users in Indonesia, especially Grab and Gojek, which are noted as the biggest online transportation service providers. The sample for this study was obtained using purposive sampling. There are several sample criteria for this study as follow: (1) Sample is an online transportation user domiciled in Indonesia; 2) Using online transportation in the last six months; (3) The age is 17 years and over.

Based on these criteria, the minimum sample suitable for this study is between $30-500$ observations following Hair et al. (2010) suggestion. Thus, this current research recruited 264 respondents to meet the sample size criteria. The data were obtained from online and offline instruments. Google form was used in online data collection, and respondents were recruited from SMEs Social Media group. A self-administered questionnaire was used in offline data collection.

The data in this study were analyzed using Variance Based SEM or Partial Least Squares (PLS). Three steps were taken in the data analysis process: (1) examination of the external model; (2) evaluation of the internal model; (3) hypothesis testing (Hussein, 2015). The data in this study were analyzed using the Structural Equation Modeling (SEM) method in conjunction with the Variance-Based SEM approach, also known as Partial Least Squares (PLS). Three stages are included in the study of PLS: an outer model analysis, inner model analysis, and hypothesis testing (Hussein, 2015).

\section{Research Instrument Development}

The research instrument in this study was in the form of a questionnaire which was built based on theory and previous studies. The table below shows the operational definitions of the variables and measurement items used in this study:

\begin{tabular}{|c|c|c|}
\hline Variable & Items & Sources \\
\hline \multirow[t]{6}{*}{$\begin{array}{l}\text { Experiential } \\
\text { Marketing }\end{array}$} & $\begin{array}{l}\text { EM1. The online transportation that I use has a fleet } \\
\text { in prime condition and is roadworthy }\end{array}$ & (Bao et al., 2016) \\
\hline & $\begin{array}{l}\text { EM2. The online transportation I use usually } \\
\text { provides a raincoat when needed. }\end{array}$ & \\
\hline & $\begin{array}{l}\text { EM3. The online transport driver I used served me } \\
\text { well. }\end{array}$ & \\
\hline & $\begin{array}{l}\text { EM4. Using online transportation services makes } \\
\text { me feel safe and comfortable. }\end{array}$ & \\
\hline & $\begin{array}{l}\text { EM5. The application of the online transportation } \\
\text { that I use is easy to operate/use. }\end{array}$ & \\
\hline & $\begin{array}{l}\text { EM6. The online transportation that I use provides a } \\
\text { variety of features that can facilitate customer } \\
\text { needs. }\end{array}$ & \\
\hline
\end{tabular}




\section{Ananda Sabil Hussein Raditha Hapsari}

\begin{tabular}{|c|c|c|}
\hline & $\begin{array}{l}\text { EM7. The attractive promotions offered to make } \\
\text { me happy to travel using online transportation } \\
\text { services. } \\
\text { EM8. There is good interaction between the driver } \\
\text { and me. } \\
\text { EM9. I feel the service is satisfactory. } \\
\text { EM10. When people talk about safe online } \\
\text { transportation, the main priority that comes to my } \\
\text { mind is Grab or Gojek. }\end{array}$ & \\
\hline Loyalty & $\begin{array}{l}\text { LOY1. I always use Grab or Gojek services } \\
\text { LOY2. I'm interested in using it again at another } \\
\text { time. } \\
\text { LOY3. The easy payment system makes me use it } \\
\text { repeatedly. } \\
\text { LOY4. I would recommend it to friends and family. } \\
\text { LOY5. I will say positive things about the online } \\
\text { transportation I use to others. } \\
\text { LOY6. I think Grab, and Gojek are the main } \\
\text { choices for online transportation services. } \\
\text { LOY7. I am not interested in using other online } \\
\text { transportation services. }\end{array}$ & $\begin{array}{l}\text { (Khan, Rahman and } \\
\text { Fatma, 2017) }\end{array}$ \\
\hline $\begin{array}{l}\text { Perceived } \\
\text { Effectiveness }\end{array}$ & $\begin{array}{l}\text { PE1. When using online transportation, I believe } \\
\text { that there is a mechanism to protect me from any } \\
\text { potential risks from using online transportation } \\
\text { PE2. I am sure that the online transportation } \\
\text { company will not harm me } \\
\text { PE3. I believe that using online transportation } \\
\text { services can make my time more efficient } \\
\text { PE4. I believe that using online transportation } \\
\text { services can make my work more effective }\end{array}$ & (Bao et al., 2016) \\
\hline Interactivity & $\begin{array}{l}\text { TWC 1. The online transportation application that I } \\
\text { use facilitates two-way communication between } \\
\text { consumers and drivers } \\
\text { TWC2. The online transportation application that I } \\
\text { use allows consumers to communicate with drivers } \\
\text { TWC3. The online transportation application that I } \\
\text { use allows consumers to communicate with the } \\
\text { application manager } \\
\text { AC1. I feel that I am in control of my experience } \\
\text { when using online transportation applications } \\
\text { AC2. When using the online transportation } \\
\text { application, I can freely choose what I want to see } \\
\text { AC3. I can freely choose what type of service I } \\
\text { want to use when using an online transportation } \\
\text { application. } \\
\text { SYNC1. The online transportation application driver } \\
\text { that I use answered my questions quickly } \\
\text { SYNC2. I can get the information I need from the } \\
\text { driver of this online application that I use very } \\
\text { quickly } \\
\text { SYNC3. The online transportation application } \\
\text { manager that I use answers my questions and/or } \\
\text { complaints quickly }\end{array}$ & $\begin{array}{l}\text { (Kim and Lee, 2019; } \\
\text { Bao et al., 2016) }\end{array}$ \\
\hline
\end{tabular}




\begin{tabular}{|c|c|c|}
\hline & $\begin{array}{l}\text { SYNC4. I can get the information I need from the } \\
\text { manager of this online application that I use very } \\
\text { quickly }\end{array}$ & \\
\hline \multirow[t]{7}{*}{ Trust } & $\begin{array}{l}\text { T1. I believe that the online transportation I use will } \\
\text { always maintain its reputation. }\end{array}$ & \\
\hline & $\begin{array}{l}\text { T2. I believe that the online transportation that I } \\
\text { use can fulfill what has been promised to the } \\
\text { customer. }\end{array}$ & \multirow[t]{6}{*}{$\begin{array}{l}\text { (Bao et al., 2016; } \\
\text { Khan, Rahman and } \\
\text { Fatma, 2017) }\end{array}$} \\
\hline & $\begin{array}{l}\text { T3. I believe that the online transportation that I } \\
\text { use always provides clear information to customers }\end{array}$ & \\
\hline & $\begin{array}{l}\text { T4. I believe that the online transportation that I } \\
\text { use has the will to provide convenience for } \\
\text { customers. }\end{array}$ & \\
\hline & $\begin{array}{l}\text { T5. I believe that the online transportation that I } \\
\text { use has good intentions to provide satisfaction to } \\
\text { customers. }\end{array}$ & \\
\hline & $\begin{array}{l}\text { T6. I believe that the online transportation drivers } \\
\text { that I use can provide quality service to customers. }\end{array}$ & \\
\hline & $\begin{array}{l}\text { T7. I believe that the online transportation driver I } \\
\text { use can pick up and drop off on time. }\end{array}$ & \\
\hline
\end{tabular}

\section{Analysis of The Inner and Outer Model}

The outer model is a measuring model used to determine the model's validity and reliability. Convergent validity is determined in PLS with reflecting indicators using loading factor (correlation between item/component scores and construct scores) indicators that measure these constructs. Convergent validity is defined as outer loading $>0.7$, communality $>0.5$, and average variance extracted (AVE) > 0.5. (Chin, 1995 in Abdillah, Willy and Jogiyanto, 2015). The discriminant validity test was conducted using the construct's cross-loading measurement. A reliability test is done to determine the measuring instrument's internal consistency. The general guideline is that alpha or composite reliability must be better than 0.7. At the same time, values as low as 0.6 are acceptable (Hair et al. in Abdillah, Willy and Jogiyanto, 2015).

The inner model is a structural model that is used to forecast the causal relationship between latent variables. Numerous metrics can be used to evaluate the inner model, including the coefficient of determination $\left(R^{2}\right)$ and predictive relevance $\left(Q^{2}\right)$.

\section{The Hypothesis Test}

For hypothesis testing using statistical values, the t-statistic value for alpha $5 \%$ is 1.96 . Thus, when the t-statistic is greater than 1.96, Ha is accepted, and $\mathrm{HO}$ is denied. To use probability to reject/accept a hypothesis, Ha is accepted if the p-value is less than 0.05. (Hussein, 2015).

\section{RESULTS AND DISCUSSION}

The respondents' characteristics in this study are shown in Table 1. 
Table 1.

Respondent Characteristics

\begin{tabular}{llcc}
\hline & & Frequency & Percentage \\
\hline \multirow{2}{*}{ Gender } & Male & 118 & $45 \%$ \\
& Female & 146 & $55 \%$ \\
& $17-25$ years old & 137 & $52 \%$ \\
& $26-35$ years old & 89 & $34 \%$ \\
& $>$ 45 years old & 38 & $14 \%$ \\
\multirow{5}{*}{ Income } & Rp 1.000.000,- & 32 & $12 \%$ \\
& Rp 1.000.001 - Rp 3.000.000,- & 134 & $51 \%$ \\
& Rp 3.000.001 - Rp 5.000.000,- & 65 & $25 \%$ \\
& $>$ Rp 5.000.000 & 33 & $13 \%$ \\
& Master Degree & 18 & $7 \%$ \\
\multirow{6}{*}{ Education } & 159 & $60 \%$ \\
& Bachelor degree & 65 & $25 \%$ \\
& High School & 22 & $8 \%$ \\
\hline
\end{tabular}

Based on Table 1, the number of female online transportation customers is more than males. From 264 respondents, dominated by respondents aged $17-25$ years (52\%) and with an income between Rp. 1,000,001 to Rp. 3,000,000 (51\%). As for education, it is dominated by respondents with bachelor's education (60\%).

\section{Analysis of the Measurement Model (Outer Model)}

There are three criteria for evaluating the outer model's utility when employing data analysis techniques with SmartPLS: convergent validity, discriminant validity, and model evaluation. In SmartPLS, the analysis of the measurement model, also known as the outer model, is used to guarantee that variables and their measurements are compatible. If the correlation coefficient between the standard reflective measurement and the construct being measured exceeds 0.70, the standard reflective measurement is high. However, for early-stage research or development, a measurement scale with a loading factor of 0.50 or 0.60 will be considered adequate (Ghozali, 2011).

\section{Convergence Validity}

Convergent Validity is concerned with establishing the validity of each relationship between indicators and latent variables. The loading factor must be greater than 0.50 . For reliability, it must be greater than 0.70 when using a composite reliability value (Hussein, 2015). Convergent validity of the measurement model with reflexive indicators is determined by the correlation between the component score and the SmartPLS-calculated latent variable or construct score.

If the loading factor is less than 0.50 , the elements in the model must be eliminated. The 0.70 cut-off value was employed in this study. The following table summarizes the outer loading 
findings for each indicator associated with each exogenous and endogenous latent variable produced by SmartPLS data processing.

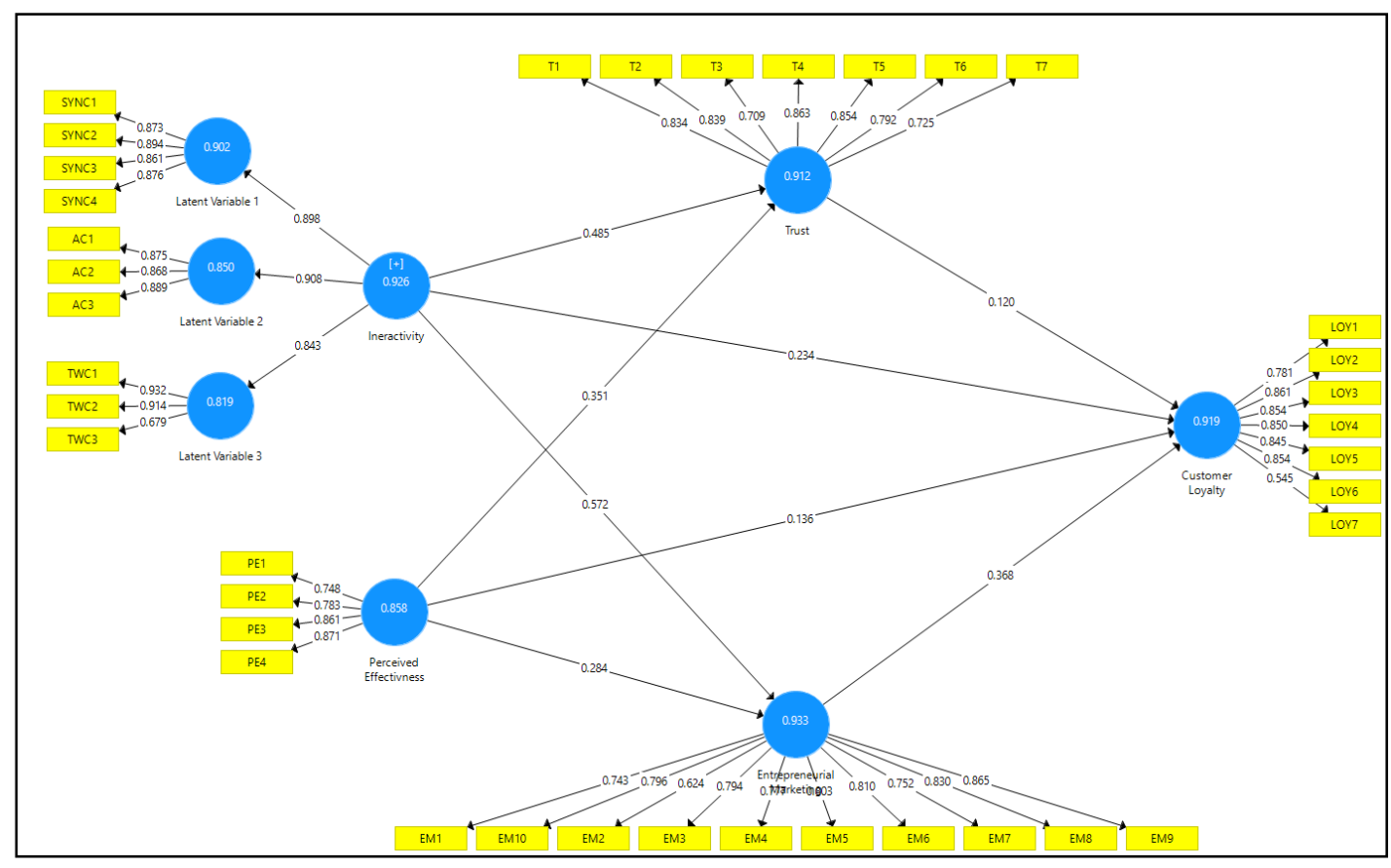

Figure 2.

Conceptual Model

Source: PLS Output, 2021

From the figure in table 6.1, it has been shown that there are still several items with a loading factor value of $<0.70$. The following is the loading factor value in the model:

Tabel 2.

Convergent Validity Test Result

\begin{tabular}{lccc}
\hline Variable & Indicator & Loading Factor & Remark \\
\hline & EM1 & 0,743 & Valid \\
EM10 & 0,796 & Valid \\
& EM2 & 0,624 & Not Valid \\
EM3 & 0,794 & Valid \\
Experiential & EM4 & 0,777 & Valid \\
Marketing & EM5 & 0,803 & Valid \\
& EM6 & 0,810 & Valid \\
& EM7 & 0,752 & Valid \\
EM8 & 0,830 & Valid \\
EM9 & 0,865 & Valid \\
& & & \\
& LOY1 & & \\
& LOY2 & 0,781 & Valid \\
LOY3 & 0,861 & Valid \\
& LOY4 & 0,854 & Valid \\
& & 0,850 & Valid \\
\hline
\end{tabular}




\begin{tabular}{lccc}
\hline & LOY5 & & \\
& LOY6 & 0,845 & Valid \\
LOY7 & 0,854 & Valid \\
PE1 & 0,545 & Not Valid \\
Effectiveness & PE2 & 0,748 & Valid \\
& PE3 & 0,783 & Valid \\
& PE4 & 0,861 & Valid \\
TWC1 & 0,871 & Valid \\
TWC2 & 0,932 & Valid \\
& TWC3 & 0,914 & Valid \\
& AC1 & 0,679 & Not Valid \\
Interactivity & AC2 & 0,875 & Valid \\
& AC3 & 0,868 & Valid \\
& SYNC1 & 0,889 & Valid \\
& SYNC2 & 0,873 & Valid \\
& SYNC3 & 0,894 & Valid \\
& SYNC4 & 0,861 & Valid \\
T1 & 0,876 & Valid \\
& T2 & 0,834 & Valid \\
& T3 & 0,839 & Valid \\
T4 & 0,709 & Valid \\
T5 & 0,863 & Valid \\
& T6 & 0,854 & Valid \\
T7 & 0,792 & Valid \\
& & 0,725 & Valid \\
\hline
\end{tabular}

Source: SmartPLS Output, 2021

The loading factor value (convergent validity) for each indicator is presented in Table 2. If the loading factor exceeds 0.70 , it is considered genuine and optimal. This table demonstrates that out of all loading factor values, three indicators have values less than 0.70 . It may be stated that all indicators within each variable conducted their measurements appropriately and following the instrument utilized.

\section{Discriminant Validity}

Discriminant Validity is a cross-loading factor value that indicates if a latent construct has an appropriate discriminant by comparing the loading value on the desired construct to the loading value on other constructs (Hussein, 2015). The discriminant validity of the measurement model with reflective indicators is determined using the construct measurement's cross-loading value.

Based on the measurement construct's cross-loading, the discriminant validity of the measurement model was determined. If the correlation between the latent construct and the size of each indicator is greater than the correlation between the latent construct and the size of the other constructs, then the latent construct better predicts the indicator than the other constructs. The discriminant validity test yields the following results: 
Tabel 3.

Discriminant Validity Test

\begin{tabular}{lrrrrr}
\hline & Loy & Exp Mktg & Interact. & P.E. & Trust \\
\hline Loyalty & 0,806 & & & & \\
Experiential Mktg & 0,758 & 0,782 & & & \\
Interactivity & 0,582 & 0,647 & 0,876 & & \\
Perceived Effectiveness & 0,690 & 0,747 & 0,718 & 0,817 & \\
Trust & 0,710 & 0,838 & 0,610 & 0,744 & 0,804 \\
\hline
\end{tabular}

Source: PLS Output, 2021

Based on the values obtained in Table 3, all the indicators that compose each of the variables in this study (the values in bold) have met the discriminant validity criteria because they have the largest outer loading value for the variables compared to other variables. Thus, all indicators in each variable in this study have met the criteria of non-discriminant validity.

\section{Model Evaluation}

Model evaluation with the square root of average variance extracted compares the AVE root value with the correlation between constructs. If the AVE root value is greater than the correlation value between constructs, then a good discriminant validity value will be achieved. The test for the analysis of the outer model is to look at the reliability value of the latent variable construct, which is measured using two indicators: composite reliability and Cronbach's alpha from the indicators that measure the construct. For both indicators, the cutoff value is 0.70 . (Hussein, 2015). The construct is declared reliable if the composite reliability value and the Cronbach alpha value are greater than 0.70 . The following is a table of evaluation results for the SmartPLS model:

Tabel 4.

Model Evaluation Test

\begin{tabular}{lcc}
\hline \multicolumn{1}{c}{ Variable } & Composite Reliability & Average Variance Extracted (AVE) \\
\hline Customer_Loyalty & 0,927 & 0,649 \\
Experiential_Marketing & 0,940 & 0,611 \\
Interactivity & 0,935 & 0,591 \\
Perceived Effectiveness & 0,889 & 0,668 \\
Trust & 0,927 & 0,647 \\
\hline
\end{tabular}

Source: PLS Output, 2021

The AVE value of all measurements of the model shows that the Composite Reliability value is greater than 0.50 , so it can be said that the evaluation of the measurement model has good discriminant validity. In addition to constructing validity tests, construct reliability tests were also carried out as measured by the criteria test, namely the composite reliability of 


\section{Ananda Sabil Hussein \\ Raditha Hapsari}

the indicators measuring the constructs. The construct is declared reliable if the composite reliability value is greater than 0.70 . In table 6.3 , it can be seen that all variables have a composite reliability value greater than 0.70 . It can be concluded that all constructs have good reliability and are quite reliable in producing consistent data. Composite reliability is to tests the level of reliability of the variable with the condition that the composite reliability value is more than 0.7. Table 6.3 shows that the composite reliability value of all variables is above the cut-off value of 0.6 . It can be concluded that all variables in this study are reliable. These results prove that all of the items on the research instrument are free from errors and deserve to be trusted, and can be used for further research.

\section{Structural Model Analysis (Inner Model)}

Inner model analysis was conducted to determine the relationship between variables, significance value, and $R$ square of the research model. The $R$ square test is a way to measure the Goodness of fit of a structural model. $R$ square $\left(R^{2}\right)$ value is used to assess how much influence the independent variable has on the dependent variable. The structural model is calculated using the resampling bootstrapping method using 500 bootstraps.

\section{Coefficient of Determination $\mathbf{R}$-square $\left(\mathbf{R}^{2}\right)$}

The coefficient of determination shows the level of strong and weak influence of the dependent variable on the independent variable.

Tabel 5.

Coefficient Determination test $\left(R^{2}\right)$

\begin{tabular}{lcc}
\hline & $\boldsymbol{R}$ Square & $\boldsymbol{R}$ Square Adjusted \\
\hline Customer_Loyalty & 0,630 & 0,624 \\
Experiential_Marketing & 0,670 & 0,667 \\
Trust & 0,635 & 0,633 \\
& & $\mathrm{GOF}=\sqrt{\overline{A V E} \times \overline{R^{2}}}=0.678 \times 0.712=0.694$
\end{tabular}

Source: PLS Output, 2021

According to Table 5, the $\mathrm{R}^{2}$ value for the Customer Loyalty variable is 0.630 ; this value indicates that 63 percent of customer loyalty can be explained by experiential marketing and 63 percent by the trust. $R^{2}$ is 0.670 for the Experiential Marketing variable and 0.635 for the Trust variable.

\section{Predictive Relevance ( $\left.\mathbf{Q}^{2}\right)$}

Predictive relevance tries to quantify the accuracy of the model's output in the study. Q2 is calculated as follows: 
Tabel 6.

Predictive Relevance (Q2)

\begin{tabular}{lccc}
\hline & SSO & SSE & $\mathbf{Q}^{2}$ (=1-SSE/SSO) \\
\hline Customer_Loyalty & 1848,000 & 852,338 & 0,539 \\
Experiential_Marketing & 2640,000 & 1273,304 & 0,518 \\
Ineractivity & 2640,000 & 1308,096 & 0,505 \\
Perceived_Effectivness & 1056,000 & 588,701 & 0,443 \\
Trust & 1848,000 & 877,110 & 0,525 \\
\hline
\end{tabular}

Source: SmartPLS Output, 2021

This research evaluates the path model's predictive usefulness using the blindfolding process. Predictive relevance $\left(Q^{2}\right)$ is frequently referred to as predictive sample reuse (Goodness of Fit Model) to validate endogenous construct models. If the value of $Q^{2}$ predictive relevance for endogenous variables is greater than the value for exogenous variables, the value is considered good (fit model). The predicted relevance value for $Q^{2}$ is 0.02 . The validity of the predicted fit model is stated to be weak; 0.15 indicates that the validity of the predictive fit model is moderate, and 0.35 shows that the validity of the predictive fit model is good. The blindfolding procedure's output will be a cross-validated redundancy estimate construct. Because SSE denotes a sum square prediction error and SSO denotes a sum squared observation, the value of $Q^{2}$ equals (1-SSE/SSO) (Setiaman, 2020). According to Table 6.5, all constructs have a $Q^{2}$ value of more than 0.35 , indicating that the fit model's predictive relevance is robust.

\section{The Goodness of Fit (GoF)}

The Goodness of fit index is used to assess the overall correctness, including both the inner and outer models. In PLS analysis, the Goodness of fit is determined using the Q-square predictive relevance $\left(Q^{2}\right)$. The GoF value is calculated as follows:

$\left((A \vee E) \times\left(R^{2}\right)\right)=0.678 \times 0.712=0.694$

According to Tenenheus (2004), if the GoF value is 0.1 , the GoF is little; if the GoF value is 0.25 , the GoF is medium; and if the GoF value is 0.38 , the GoF is high. According to the calculations above, the GoF value is more than 0.38, which equals 0.694. The $\mathrm{R}^{2}, \mathrm{Q}^{2}$, and GoF tests demonstrate that the model used in this work is robust. Thus, hypothesis testing is possible.

\section{Results of Hypothesis Testing}

Hypothesis testing is used to determine the effect of the full hypothesis given in this study, including both direct and indirect effects. By examining the results of statistical tests and the $p$ value, the conditions for testing the hypothesis can be determined. If the p-value is less than 0.05 and the statistical value is more than the t table value, namely 1.96, the hypothesis is accepted. The following statistical tests were conducted using the bootstrapping method: 
Tabel 7.

Hypothesis Testing Results

\begin{tabular}{lllll}
\hline Hypothesis & & T Stat & $\begin{array}{c}\text { P } \\
\text { Value }\end{array}$ & Remark \\
\hline H1: Ineractivity $\rightarrow$ Perceived Effectiveness & 0,898 & 65,863 & 0,000 & Supported \\
H2: Ineractivity $\rightarrow$ Trust & 0,483 & 7,051 & 0,000 & Supported \\
H3: Ineractivity $\rightarrow$ Experiential Marketing & 0,568 & 8,011 & 0,000 & Supported \\
H4: Ineractivity $\rightarrow$ Customer Loyalty & 0,240 & 3,012 & 0,003 & Supported \\
H5: Perceived Effectivness $\rightarrow$ Trust & 0,353 & 5,768 & 0,000 & Supported \\
H6: Perceived Effectivness $\rightarrow$ Experiential & 0,288 & 4,069 & 0,000 & Supported \\
Marketing & & & & Not \\
H7: Perceived Effectivness $\rightarrow$ & 0,137 & 1,749 & 0,081 & Supported \\
Customer_Loyalty & 0,121 & 1,461 & 0,145 & Not \\
H8: Trust $\rightarrow$ Customer_Loyalty & 0,359 & 4,254 & 0,000 & Supported \\
H9: Experiential_Marketing $\rightarrow$ CustomerLoyalty & 0 & & & \\
\hline SOurce: PLS Analysis,2021 & & &
\end{tabular}

\section{Discussions}

This current research examines the effect of interactivity, perceived effectiveness, trust, and experiential marketing on online transportation customers' loyalty in Indonesia. Seven out of nine hypotheses were accepted as a result of the data analysis. Interactivity, and experiential marketing have proven to be the antecedents of customer loyalty. While the perceived effectiveness does not show a significant influence on loyalty, this construct appears to be the predictor of experiential marketing. This means, in order to enhance customer loyalty toward online transportation, the service provider should pay attention to experiential marketing and interactivity. Furthermore, this research found that perceived effectiveness is the robust predictor of trust and experiential marketing. Thus, to ensure that the online transportation customers have a pleasant experience with online transportation, the service providers must enhance the mechanism to protect consumers from any potential risks from using online transportation.

While some previous studies Lee et al. (2015) did not test the impact of interactivity on perceived effectiveness, trust, loyalty. This current research proves that interactivity plays an important role in enhancing perceived effectiveness, trust, and loyalty. These findings support another study on various industry such as a study done by Cyr, Head and Ivanov (2009), which found that interactivity has a significant positive effect on perceived effectiveness and trust; and a study done by Ting, Abbasi and Ahmed (2021) which found that interactivity is a robust predictor of customer loyalty. 
This current research noted that Interactivity was found to be the biggest effect on perceived effectiveness. This finding suggests that the contact between consumers and service providers has a significant impact on consumers' perceived efficacy. As a result, businesses must enable two-way communication between consumers and service providers, for example, by allowing consumers to submit queries and comments to online transportation drivers and application managers. Additionally, the established two-way communication must ensure that all kinds of consumer communication respond quickly and properly.

However, we were unable to substantiate the hypothesis that perceived efficacy increases customer loyalty. This result contrasts with Lehto and Oinas-Kukkonen (2015); Huang et al. (2015); Fang et al. (2014). Additionally, this current research could not support the hypothesis that trust enhances customer loyalty, which contradicts prior findings from (Lin et al., 2011; Kang and Hur, 2012; Frasquet, Descals and Ruiz-Molina, 2017; Park, Kim and Kwon, 2017). Following these findings, only interactivity and experiential marketing have a discernible effect on client loyalty. This study found that perceived effectiveness directly affects experiential marketing, and the experiential marketing construct also directly affects customer loyalty. Thus, perceived effectiveness might have a full mediation effect on loyalty through experiential marketing, which makes the direct effect of the construct insignificant toward customer loyalty. The insignificant effect of trust on customer loyalty might be associated with the concept of online platform services. In online platform services, especially the established ones, the customer might pay more attention to user interface quality and user experience quality.

Furthermore, based on the respondents' characteristics, most respondents are the Gen-Zs which accounted for $52 \%$ of the total population. The Gen-Zs might have their characteristics that focus more on the perceived effectiveness and experience. Priporas, Stylos and Fotiadis (2017) noted that the Gen-Zs expect various new devices and electronic processes to be widely available. They demand the ease and speed of transactions (effectiveness), information provision (interactivity), and convenience (experience).

As a result of the findings, we conclude that in Indonesia, high customer trust and perceived effectiveness in online transportation are not predictive of customer loyalty. However, suppose a business can establish a positive experience through its marketing operations that is based on trust and perceived efficacy. In that case, there is a significant probability that the business can develop a loyal consumer. To increase customers' willingness to use the application in the future, businesses must ensure that consumers have a favorable and enjoyable experience when utilizing online transportation services. 


\section{Ananda Sabil Hussein \\ Raditha Hapsari}

\section{CONCLUSION}

The hypothesis testing supported seven of the nine hypotheses proposed. The findings of this study indicate that interaction is a significant predictor of online transportation consumer loyalty. This research shows that interactivity and experiential marketing are the robust antecedents of online transport loyalty. While the perceived effectiveness construct does not show a significant effect on loyalty, the constructs have proven to be the predictor of experiential marketing. This research makes a theoretical and practical contribution. The first and the most notable theoretical contribution is formed by elucidating the antecedents of online transportation customer loyalty. This research provides a complex model of online transportation loyalty by integrating other important constructs that previous research has not widely explored. Practically, this research can be used by online transport practitioners to enhance customer loyalty by ensuring that they provide a positive experience through an interactive and effective service activity. However, because this study used a purposive sampling technique, it may only be extended to other industrial settings and conditions with extreme caution.

Additionally, we strongly recommend that future research do an exploratory study to determine why a high level of trust and perceived effectiveness did not increase customer loyalty for online transportation services based on the current study's findings. Furthermore, integrating other important marketing constructs will capture the antecedents of online transportation customer loyalty more clearly. Furthermore, considering using S-D logic theory and incorporating the co-creation construct might enhance the model's predictive power.

\section{REFERENCES}

Abdillah, Willy and Jogiyanto. 2015. Partial Least Square (PLS) Alternatif Structural Equation Modeling (SEM) dalam Penelitian Bisnis. Ed. 1. Yogyakarta: ANDI.

Adaji, I. and Vassileva, J. 2017. Perceived Effectiveness, Credibility and Continuance Intention in E-commerce: A Study of Amazon. Lecture Notes in Computer Science: 293-306.

Ahn, J. and Back, K.-J. 2018. Influence of brand relationship on customer attitude toward integrated resort brands: a cognitive, affective, and conative perspective. Journal of Travel and Tourism Marketing, 35(4): 449-60.

Bao, H., Li, B., Shen, J. and Hou, F. 2016. Repurchase intention in the Chinese e-marketplace: Roles of interactivity, trust and perceived effectiveness of e-commerce institutional mechanisms. Industrial Management and Data Systems, 116(8): 1759-1778.

Boateng, S.L. 2019. Online relationship marketing and customer loyalty: a signaling theory perspective. International Journal of Bank Marketing, 37(1): 226-240. 
Carayannis, E.G., Grigoroudis, E., Del Giudice, M., Della Peruta, M.R. and Sindakis, S. 2017. An exploration of contemporary organizational artifacts and routines in a sustainable excellence context. Journal of Knowledge Management, 21 (1): 35-56.

Chaney, D., Lunardo, R. and Mencarelli, R. 2018. Consumption experience: past, present and future. Qualitative Market Research: An International Journal, 21 (4): 402-420.

Chang, W.J. 2020. Experiential marketing, brand image and brand loyalty: a case study of Starbucks. British Food Journal.

Chung, K.-S., Brown, C. and Willett, J. 2019. Korean MLB players: the effects of motives and identification on fan loyalty. Business and Management: An International Journal, 9(3): 239-54.

Cyr, D., Head, M. and Ivanov, A. 2009. Perceived interactivity leading to e-loyalty: Development of a model for cognitive-affective user responses. Journal of HumanComputer Studies, 67: 850-869.

Das, G. 2016. Antecedents and consequences of trust: an e-tail branding perspective. International Journal of Retail and Distribution Management, 44(7): 713-730.

Dawes, J., Meyer-Waarden, L. and Driesener, C. 2015. Has brand loyalty declined? A longitudinal analysis of repeat purchase behavior in the UK and the USA. Journal of Business Resea, 68(2): 425-432.

Ding, C.G. and Tseng, T.H. 2015. On the relationships among brand experience, hedonic emotions, and brand equity. European Journal of Marketing, 49(7/8): 994-1015.

Etemad-Sajadi, R. 2016. The impact of online real-time interactivity on patronage intention: the use of avatars. Computers in Human Behaviour, 61 (1): 227-232.

Fang, Y.H., Qureshi, I., Sun, H., Mccole, P., Ramsey, E. and Lim, K.H. 2014. Trust, satisfaction and online repurchase intention: the moderating role of perceived effectiveness of ecommerce institutional mechanisms. MIS Quarterly, 38: 407-427.

Foroughi, B., Iranmanesh, M., Gholipour, H.F. and Hyun, S.S. 2019. Examining relationships among process quality, outcome quality, delight, satisfaction and behavioural intentions in fitness centres in Malaysia. International Journal of Sports Marketing and Sponsorship, 20(3): 374-89.

Frasquet, M., Descals, A.M. and Ruiz-Molina, M.E. 2017. Understanding loyalty in multichannel retailing: the role of brand trust and brand attachment. International Journal of Retail and Distribution Management, 45(6): 608-625.

Gbadamosi, A. 2015. Brand personification and symbolic consumption among ethnic minority 


\section{Ananda Sabil Hussein \\ Raditha Hapsari}

teenage consumers: An empirical study. Journal Brand Management, 22: 737-754.

Giddens. 2002. Customer Loyalty: Menumbuhkan dan Mempertahankan Kesetiaan Pelanggan. Edisi Revi ed. Jakarta: Erlangga.

Hair, J.F., Black, W., Babin, B. and Anderson, R. 2010. Multivariate data analysis.

Huang, Q., Chen, X., Ou, C.X., Davison, R.M. and Hua, Z. 2015. Understanding buyers' loyalty to a $\mathrm{C} 2 \mathrm{C}$ platform: the roles of social capital, satisfaction and perceived effectiveness of e-commerce institutional mechanisms. Information Systems Journal, 27(1): 91-119.

Hussein, A.S. 2015. Penelitian bisnis dan manajemen menggunakan partial least squares (PLS) dengan smart PLS 3.0: Modul ajar jurusan manajemen fakultas ekonomi dan bisnis. Unversitas Brawijaya.

Hussein, A.S. and Hapsari, R. 2020. Heritage experiential quality and behavioural intention: lessons from Indonesian heritage hotel consumers. Journal of Heritage Tourism: 1-20.

Islam, T., Islam, R., Pitafi, A.H., Xiaobei, L., Rehmani, M., Irfan, M. and Mubarak, M.S. 2021. The impact of corporate social responsibility on customer loyalty: The mediating role of corporate reputation, customer satisfaction, and trust. Sustainable Production and Consumption.

Kalantari, H., D. and Johnson, L. 2018. Australian customer willingness to pay and wait for masscustomised products. Asia Pacific Journal of Marketing and Logistics, 30(1): 106-120.

Kandampully, J., Zhang, T.C. and Bilgihan, A. 2015. Customer loyalty: a review and future directions with a special focus on the hospitality industry. International Journal of Contemporary Hospitality Management, 27(3): 379-414.

Kang, S. and Hur, W.-M. 2012. Investigating the antecedents of green brand equity: a sustainable development perspective. Corporate Social Responsibility and Environmental Management, 19(6): 306-316.

Khan, I., Rahman, Z. and Fatma, M. 2016. The role of customer brand engagement and brand experience in online banking. International Journal of Bank Marketing, 34(7): 1025-1041.

Khan, I., Rahman, Z. and Fatma, M. 2017. The role of customer brand engagement and brand experience in online banking. International Journal of Bank Marketing, 34(7): 1025-1041.

Kim, J. and Lee, K.H. 2019. Influence of integration on interactivity in social media luxury brand communities. Journal of Business Research, 99: 422-429.

Kim, Y.D., Magnusen, M.J., Kim, Y. and Kim, M. 2020. Developing a sport fan equity index. International Journal of Sports Marketing and Sponsorship, 21 (2): 247-66. 
Krystallis, A. and Chrysochou, P. 2014. The Effects of Service Brand Dimension on Brand Loyalty. Journal of Retailing and Consumer Services, 21 (2).

Lee, D., Moon, J., Kim, Y.J. and Yi, M.J. 2015. Antecedents and consequences of mobile phone usability: Linking simplicity and interactivity to satisfaction, trust, and brand loyalty. Information and Management, 52(3): 295-304.

Lee, M.T.H. 2021. The impact of brand love on brand loyalty: the moderating role of selfesteem, and social influences. Spanish Journal of Marketing - ESIC.

Lehto, T. and Oinas-Kukkonen, H. 2015. Explaining and predicting perceived effectiveness and use continuance intention of a behaviour change support system for weight loss. Behaviour Information Technology, 34(2): 176-189.

Leonidou, L.C., Kvasova, O. and Leonidou, C.N. 2013. Business Unethicality as an Impediment to Consumer Trust: The Moderating Role of Demographic and Cultural Characteristics. Journal of Business Ethics: 397-415.

Levy, S. and Guterman, H, G. 2020. Twofold impact of experiential marketing: manufacturer brand and hosting retailer. EuroMed Journal of Business.

Lin, C.-P., Chen, S.-C., Chin, C.-K. and Lee, W.-Y. 2011 . Understanding purchase intention during product-harm crises: moderating effects of perceived corporate ability and corporate social responsibility. Journal of Business Ethics.

Liu, Y., Cheng, P. and Ouyang, Z. 2021. How trust mediate the effects of perceived justice on loyalty: A study in the context of automotive recall in China. Journal of Retailing and Consumer Services, 58.

Markovic, S., Iglesias, O., Singh, J.J. and Sierra, V. 2018. How does the perceived ethicality of corporate services brands influence loyalty and positive word-of-mouth? Analyzing the roles of empathy, affective commitment, and perceived quality. Journal of Business Ethics, 148(4): $721-740$.

Meng-Shiou, C., Li-Fen, L. and Li-Wen, C. 2019. Study on the factors affecting revisiting intention by SEM analysis. International Journal of Organizational Innovation, 11 (4): 285-296.

Molinillo, S., Gomez-Ortiz, B., Pérez-Aranda, J. and Navarro-García, A. 2017. Building customer loyalty: The effect of experiential state, the value of shopping, and trust and perceived value of service on online clothes shopping. Clothing and Textiles Research Journal, 35(3): $156-171$.

Nguyen, T.D., Barrett, N.J. and Miller, K.E. 2011. Brand loyalty in emerging markets. Marketing Intelligence and Planning, 29(3): 222-232. 


\section{Ananda Sabil Hussein \\ Raditha Hapsari}

O'Connor, C. and Kelly, S. 2017. Facilitating knowledge management through filtered big data: SME competitiveness in an agri-food sector. Journal of Knowledge Management, $21(1): 156-179$.

Park, C., Jun, J.K. and Lee, T.M. 2015. Do mobile shoppers feel smart in the smart phone age? International Journal Mobile Communication, 13(2): 157-171.

Park, E., Kim, K.J. and Kwon, S.. 2017. Corporate social responsibility as a determinant of consumer loyalty: an examination of ethical standard, satisfaction and trust. Journal of Business Research, 76: 8-13.

Priporas, C. V., Stylos, N. and Fotiadis, A.K. 2017. Generation Z consumers' expectations of interactions in smart retailing: A future agenda. Computers in Human Behavior, 77: 374381.

Purwanto, P. and Kuswandi, K. 2017. Effects of Flexibility and Interactivity on the Perceived Value of and Satisfaction with E-Commerce (Evidence from Indonesia). Market-Tržište, 29(2): 139-159.

Putri, U.M., Amin, M. and Warjio. 2019. Development of Online Transportation Services: Effectiveness and Efficiency of The Grabbike Applications for Society in Medan City. International Journal of Research in Business and Social Science, 8(4): 71-78.

Raza, A., Rather, R.A., Iqbal, M.K. and Bhutta, U.S. 2020. An assessment of corporate social responsibility on customer company identification and loyalty in banking industry: a PLSSEM analysis. Management Organization Review.

Romaniuk, J. and Thiel, M, N. 2013. Behavioral Brand Loyalty and Consumer Brand Associations. Journal of Business Research, 66(1).

Schmitt, B.H. 1999. Experiential Marketing: How to Get Customer to Sense, Feel, Think, Act, Relate to Your Company and Brands. New York: Free Press.

Sonderlund, M. 2018. he proactive employee on the floor of the store and the impact on customer satisfactio. Journal of Retailing and Consumer Services, 43(C): 46-53.

Storey, J. 2017. Theories of Consumption. Routledge.

Ting, D.H., Abbasi, A.Z. and Ahmed, S. 2021. Examining the mediating role of social interactivity between customer engagement and brand loyalty. Asia Pacific Journal of Marketing and Logistics, 33(5): 1139-1158.

Venkatesh, V., Thong, J.Y.L. and XU, X. 2012. Consumer acceptance and use of information technology: extending the unified theory of acceptance and use of technology. MIS Quarterly, 36(1): 157-178. 
Wiedmann, K.P., Labenz, F., Haase, J. and Hennigs, N. 2018. The power of experiential marketing: exploring the causal relationships among multisensory marketing, brand experience, customer perceived value and brand strength. Journal of Brand Management, 25(2): 101-118.

Yeh, T.M., Chen, S.H. and Chen, T.F. 2019. The relationships among experiential marketing, service innovation, and customer satisfaction-A case study of tourism factories in Taiwan. Sustainability, 11 (4): 1041-1052.

Yoo, W.S., Yunjung, L. and Jung, K.P. 2010. The role of interactivity in etailing: Creating value and increasing satisfaction. Journal of Retailing and Consumer Services, 17: 89-96.

Zheng, X., Lee, M. and Cheung, C.M.K. 2017. Examining e-loyalty towards online shopping platforms. Internet Research, 27(3): 709-726. 